\title{
Professionalisation of short-term rentals and emergent tourism gentrification in post-crisis Thessaloniki
}

Philipp Katsinas, London School of Economics and Political Science

\begin{abstract}
This paper contributes to research on short-term rentals (STRs), their suppliers and their impact on housing and the local community, focusing on Thessaloniki, a recessionary city off the tourist map until recently. Through the conduction of in-depth interviews with hosts and other key informants, and the analysis of quantitative data on Airbnb listings, I argue that: (1) far from enabling a sharing economy, Airbnb facilitates (re)investment in housing by different types of hosts. But investors outcompete amateur hosts and contribute to the professionalisation of STRs and the concentration of revenues. (2) the extraction of higher rents through STRs leads to the displacement of tenants and to gentrification in cities previously considered as ungentrifiable, driven by increased tourism and the short-term character of these rentals. However, the type and scale of investors involved, and the impact of gentrification are conditioned by contextual differences and the position of cities in the international competition to attract tourists.
\end{abstract}




\section{Introduction}

A workshop held at a creative space in the city centre of Thessaloniki in early May 2018 is a telling example of the ongoing frenzy about short-term rentals (STRs) in Greece. Entitled 'Airbnb, all you need to know about successful hosting', the well-attended event included presentations by professional hosts and a property management company on how to market listings on the various platforms, on the legal framework and tax regime by a lawyer and an accountant respectively, and on real estate investment opportunities in STRs in Thessaloniki by a group of students from a US university. Such workshops are not uncommon and reflect both the uncertainty regarding the regulation of these rentals and the growing professionalisation of the sector. Different types of hosts compete for visitors, and property management companies have become popular by offering services including cleaning, user profile management, and booking assistance.

A quinquennium after the explosion of interest in STR hosting in Greece, the imaginary of individualised coping with economic recession through this new market for rental housing is common, while for many it has become a lucrative business opportunity given the construction of tourism as the growth engine of the economy. Following the economic adjustment programmes imposed on the Greek state, tourism was one of the few sectors that were not negatively affected. The number of international visitors to the country increased from 15 million in 2010 to more than 30 million in 2018 (World Bank, 2020). This trend also reached Thessaloniki, the country's second largest city, which lacked tourist appeal until recently, with the more than doubling in the number of international visitors boosted by the local government's urban branding strategy. Here too, tourism has been celebrated as the saviour for the declined urban economy, not only 
by politicians and business elites, but also by a segment of homeowners sensing the increased demand for their properties by visitors.

The growth in urban tourism and STRs has been at the centre of interest in cities globally, with much rejoice about the benefits of the so-called sharing economy. Simultaneously, there have been concerns about and contestation against the detrimental effects that the conversion of housing from residential to short-term use may have on urban living and housing affordability for part of the population. Several scholars argue that STRs are not a sharing economy, having led to the concentration of property ownership and revenues to professional hosts and investors, and reinforced gentrification and displacement of residents, professionals and other users of space (Arias-Sans and Quaglieri-Dominguez, 2016; Cocola-Gant and Gago, 2019; Wachsmuth and Weisler, 2018; Yrigoy, 2019). While this argument has been developed in major and tourist cities already affected by gentrification processes (but see Ioannides et al., 2018; Mermet, 2017), little is known about the structure and provision of STRs and their impact on housing in cities that face less tourism pressure and/or are regarded as ungentrifiable, because of their socio-economic, aesthetic and urban-environmental characteristics that impede the process (Ley and Dobson, 2008; Maloutas, 2018).

This paper focuses on Thessaloniki ${ }^{1}$, a recessionary city in the European south, and addresses (1) the question of who the suppliers of STRs are and how the process of professionalisation occurs; and (2) the impacts that the proliferation of STRs has on housing in cities where gentrification had previously been limited. In addition to the analysis and mapping of data on Airbnb listings, I conducted in-depth interviews with 
different types of hosts, tenants and other key informants between 2017 and 2019 to identify the providers of STRs.

The paper highlights how, far from being a sharing economy, digital platforms like Airbnb primarily constitute an instrument for renewed investment in rental housing for different types of investors. In cities in the European semi-periphery, STRs offer the opportunity to homeowners to profit from increased demand by visitors, providing an urgently needed income to marginal hosts during economic recession (Semi and Tonetta, 2020) and a speculative investment vehicle to transnational investors (Cocola-Gant and Gago, 2019). This research illustrates the role of local property owners and investors in becoming professional multi-listing hosts, in contexts in which corporate real estate investment is not as profound, reflecting the specificities of the housing system (Allen et al., 2008; Arbaci, 2019).

These specificities previously impeded gentrification in Thessaloniki, but I argue that STRs provide a (tourism) gentrification impetus in cities where the process had been limited. Gentrification is sparked by the higher profitability that the short-term nature of this type of rental provides, the increase in extra-local demand and the opportunity to reach a global market of tourists, and the associated reinvestment in housing (CocolaGant and Gago, 2019; Wachsmuth and Weisler, 2018). Increased demand leads to more competition for rental housing, and to the displacement of tenants and their substitution by visitors. Additionally, exclusionary displacement is caused by the increase in rents for long-term rentals and the reduction in the available affordable housing stock. However, the impact of gentrification is highly concentrated spatially and mitigated by contextual differences and the position of the city in the international competition for tourists. 


\section{Short-term rentals, hosts and tourism gentrification}

STRs have emerged as a new category of housing between long-term rentals and formal tourist accommodation, becoming popular in an increasing number of places internationally. They have been one of the main drivers of the so-called sharing economy, primarily mediated by corporate digital platforms such as Airbnb, Homeaway, Booking.com etc., which have acquired an oligopolistic position in the market. Proponents of the sharing economy view it as an emerging culture of collaboration redefining and destabilizing market-oriented consumerism, supplanting corporateoriented capitalism (Botsman and Rogers, 2011; Sundararajan, 2016). Online platforms have been eager to defend this business model, pointing to the supposed redistributive effects of STRs for hosts through the occasional sharing of homes. Occasional homesharing, the argument goes, allows struggling households to cope in a period of austerity and stay put in their neighbourhoods through this additional income (Sperling, 2015).

On the contrary, critics of Airbnb and the corporate, online platform mediated, for-profit sharing economy have argued that their model is not based on sharing, but rather constitutes an innovative rental practice requiring regulatory policy interventions (Kallis, 2017; Slee, 2017). Critical scholars have claimed that permanent letting to visitors and professionalisation are key outcomes of the proliferation of STRs. Research in tourist cities (Arias-Sans and Quaglieri-Dominguez, 2016; Cocola-Gant and Gago, 2019; Kadi et al., 2019; Slee, 2017; Wachsmuth and Weisler, 2018) substantiates that a large percentage of STR properties are entire homes which, rather than being occasionally rented out for a supplemental income by individuals, are run professionally throughout the year. The spatial distribution of revenues in urban areas has also been 
scrutinised, showing that STRs are concentrated in and around city centres, close to tourist attractions, hotels and public transport, and to gentrified areas offering night-life and leisure activities (Arias-Sans and Quaglieri-Dominguez, 2016; Gutierrez et al., 2017; Ioannides et al., 2018; Schäfer and Braun, 2016). But far less is known about who the hosts are. Quantitative analyses have demonstrated that a limited number of professional hosts, including investors and property management companies, own or manage multiple listings and large property portfolios (Arias-Sans and Quaglieri-Domınguez, 2016; Cocola-Gant, 2016; Gurran and Phibbs, 2017; Schäfer and Braun, 2016; Wachsmuth and Weisler, 2018). Recent qualitative studies (Cocola-Gant and Gago, 2019; Semi and Tonetta, 2020) have provided more details in this respect, but still leave open questions about other actors' involvement in STRs and alternative strategies of professionalisation. Semi and Tonetta (2020) show how middle-class homeowners become 'marginal hosts' in Turin, as STRs provide the opportunity for value extraction from housing in a period of austerity. Among marginal hosts, they differentiate between two groups: hosts who rely on assets they already owned and others who have purchased further properties, but still remain marginal regarding the scale of their operations. Focusing on Lisbon, CocolaGant and Gago (2019) argue that international individual and corporate investors are increasingly replacing local providers of STRs in a process of professionalisation through buy-to-let investment (Paccoud, 2017). Investors take advantage of the flexibility that STRs provide in the management of a rental property, due to the growth of digital technologies and the expansion of property management companies (Fields, 2019), which contributes to further housing financialisation (Cocola-Gant and Gago, 2019). 
Several scholars (Cocola-Gant, 2016; Lee, 2016; Wachsmuth and Weisler, 2018; Yrigoy, 2019) argue that the proliferation of STRs has exacerbated gentrification and touristification in cities. Tourism has been analysed as a force reshaping cities (Judd and Fainstein, 1999; Maitland, 2010), but the link between urban tourism and gentrification has only recently been explored. In this respect, it has been argued that tourism results in displacement of residents, professionals and users of space (Colomb and Novy, 2017; Gotham, 2005). Cocola-Gant (2018) contends that increased tourism and the associated intensification of land use accelerate residential and commercial gentrification, as land values are driven up. Specifically regarding STRs, Wachsmuth and Weisler (2018) use a rent gap model to describe the process: Homeowners can make a larger profit by renting their properties to tourists rather than full-time to residents, creating rent gaps between the current revenue from long-term rentals and the potential revenue realised through Airbnb. These rent gaps are globally scaled, but geographically uneven, mainly created by extra-local demand in areas attractive to tourists that have already undergone gentrification (Wachsmuth and Weisler, 2018). Given the prospects for the increased extraction of rental incomes, landlords have converted their properties to STRs, leading to direct displacement of tenants through eviction, to exclusionary displacement due to the reduction of the (affordable) rental housing stock, and to the increase in rental prices (Cocola-Gant, 2016; Wachsmuth and Weisler, 2018).

While the contribution of STRs to gentrification has been established, it is less clear what happens in cities where the process was previously limited or inexistent, such as secondary cities in the European south. Several factors have been identified to impede gentrification, including urban/regional/national growth trends and the functional base of 
the economy, the type and quality of the housing stock and security in tenure (Ley and Dobson 2008; Shaw, 2005; Smith, 1996). But gentrification has globalised in recent decades and become embedded in the increased mobility of policies, including gentrification blueprints, and international capital invested in land markets (Lees et al., 2016; Slater, 2017; Wyly, 2015). And peripheral economies, given their position in the international distribution of labour, increasingly compete for the attraction of capital and consumption through tourism, creating new investment opportunities in real estate, while higher-income visitors offset the low demand by the local middle-class (Cocola-Gant, 2018). Such developments have been identified in Porto (Carvalho et al., 2019), Seville (Jover and Diaz-Parra, 2019) and Turin (Semi and Tonetta, 2020). Like Thessaloniki, these cities had in the past undergone processes of suburbanisation and/or deindustrialization, while gentrification had been of minor importance, due to contextual factors and the relative negligibility of potential gentrifiers. Using the case of Thessaloniki, I argue that tourism growth and the proliferation of STRs play an important role in transforming housing investment and contribute to gentrification and displacement in secondary cities in southern Europe.

\section{Thessaloniki: the crisis footprint on a tourist destination in the}

\section{making}

Despite Greece being a popular tourist destination, Thessaloniki was until recently off the tourist map. The city's economy has been in crisis since the 1990s (Karaliotas, 2017; 
Labrianidis, 2011) due to deindustrialisation, capital flight, and failed neoliberal reform attempts, in an era marked by corruption scandals in the local and regional administrations. The municipal government attempted to rebrand Thessaloniki during the last decade in order to attract tourists and investments (Katsinas, 2019) through the promotion of the city's historical and cultural heritage, the implementation of tourismand leisure-oriented urban regeneration projects in the city centre, and agreements with low-cost airlines. This tourism offensive was crowned with success, leading to an $150 \%$ increase in the number of overnight stays by international visitors in the city's hotel industry since 2010 to over 1.3 million (Thessaloniki Hotel Association, 2020), to the opening of more than 30 new hotels and hostels, and to the flourishing of STRs. Nevertheless, the number of international tourists is not comparable to other Southern European cities of a similar size (Geerts, 2018).

Thessaloniki is characterised by high rates of homeownership and owneroccupation, the high percentage and significance of secondary housing and the nearcomplete absence of a social housing sector (Allen et al., 2008). Its urban landscape is dominated by several storey apartment buildings, the result of the post-WWII (re)construction of the city through the antiparochi system - an informal and not-taxable agreement between the owner of a land plot (built or not) and a developer without direct state involvement (Maloutas, 2003; Mantouvalou et al., 1995). Fragmentation of land holdings and ownership resulted in the fragmentation of building production and made the involvement of major capital-intensive companies in the building sector unprofitable (Mantouvalou et al., 1995). Landowners were granted some of the apartments (depending on the total volume built and the land price), while the constructors could sell the 
remaining. The extra apartments that landowners acquired, were rented out, providing an extra source of income, and/or served their extended family. As a result, antiparochi contributed to the extreme segmentation and social diffusion of property and to changes in economic and social status, as broad social strata were transformed to a lower middleclass of homeowners and landlords. The increased building density due to antiparochi contributed to the suburbanisation of parts of the middle and upper classes and to the disuse of a large part of the housing stock, especially of smaller apartments on lower floors and basements (Kafkalas et al., 2008). Since the 1980s the municipality of Thessaloniki lost 22\% of its population to 325,182 inhabitants (ELSTAT, 2011), while the rest of the urban area continued to grow (the population of the Urban Area of Thessaloniki was 789,191 in 2011). The percentage of owner-occupation in the municipality of Thessaloniki amounts to $62.7 \%$, while the housing vacancy rate is $28 \%$, translating to 58,022 vacant housing units. In parts of the city centre vacancy is even higher, with one in three homes empty according to the 2011 census $^{2}$ (ELSTAT, 2011).

The Greek sovereign debt crisis and the implemented austerity measures during the last decade severely impacted housing and paved the way for the restructuring of the housing market (Emmanuel, 2014; Hadjimichalis, 2018; Maloutas, 2014). As part of the economic adjustment programs, a new real estate property tax was introduced with the goal to increase public revenues (Alexandri and Janoschka, 2018). This property tax, in conjunction with rising unemployment and impoverishment, led to the progressive transformation from a public to a private debt crisis and the twofold indebtedness of households towards the state, through the increased taxation of property, and towards banks, through the increasing inability to pay off mortgages (Hadjimichalis, 2018). As a 
result, homeownership has been turned from a strategic resource and safety net for family welfare into a burden for a large part of the population (Alexandri and Janoschka, 2018; Beswick et al., 2017). Private indebtedness has resulted in evictions, foreclosures, and the confiscation of the money deposited in bank accounts, disproportionally affecting the lower and middle classes, although foreclosures and housing auctions of primary residences have been largely prevented so far, due to the existing legal framework and citizen activism physically stopping housing auctions at court (Siatitsa, 2016).

In the period since 2008 , residential property prices decreased substantially, with a cumulative reduction of $45 \%$ in average housing prices in Thessaloniki until 2018 (Bank of Greece, 2020) due to the collapse of the mortgage market and increased property taxation. Nevertheless, real estate transactions have been very low (ELSTAT, 2018) and housing construction has been minimal in the municipality of Thessaloniki, with only 192 new housing units built in 2018 (ELSTAT, 2019), thus putting pressure on the existing housing stock. Real rents started to fall in 2010 (Emmanuel, 2014), as the decreasing ability of tenants to pay former rent levels did not result in a dramatic rise in evictions, but rather to negotiations with landlords and to rent reductions. This was due to the social profile of private landlords, the majority of whom are small property owners directly dependent on income from rents (Maloutas, 2014; Sapounakis and Katapidi, 2017). It is in this context of relatively low long-term rental prices that Airbnb and STRs provided a new rent seeking strategy to households owning second/multiple properties, and at the same time created the potential for real estate speculation for landlords, property management companies and investors. 


\section{Methodology}

In order to analyse the impact of STRs on housing in Thessaloniki, data on Airbnb listings in the municipality of Thessaloniki were utilised, that were obtained from the consulting firm AirDNA, which performs regular scrapes of the Airbnb website and aggregates the data. The dataset includes information on the type of listing, prices and other variables, and estimates of occupancy and revenue. As the latter are only algorithmic estimates of Airbnb activity, there may be concern about their accuracy. But, Ioannides et al. (2018), by crossreferencing the AirDNA dataset in Utrecht to a sample of Airbnb listings for which owners shared information with them, argue that AirDNA overestimated the number of bookings, nights booked and revenue by on average $8 \%$ to $15 \%$, nonetheless making this the most accurate estimate available. The dataset includes 4731 listings in the municipality of Thessaloniki advertised on Airbnb between January 2016 and July 2019. Airbnb listings were mapped and compared to data on housing tenure and housing vacancy from the 2011 Greek General Population Census (ELSTAT, 2011) at building block level to estimate the amount of housing converted into STRs. While there may be issues with the accuracy of the census data several years after it was conducted, no more recent detailed data on housing in Thessaloniki are available. These data and the listings were then aggregated at neighbourhood scale in 25 neighbourhoods of the municipality ${ }^{3}$.

The quantitative data were complemented by 20 in-depth interviews conducted between 2017 and 2019 with Airbnb entire-home hosts. These included single-listing hosts and more professional multiple-listing hosts, and representatives of property management companies managing larger portfolios of properties, in order to identify the providers of STRs. The conduction of interviews with hosts contributed to the analysis of the social 
composition of the STR sector in the city, pointing at its heterogeneity and the strategies of different types of hosts. The interviewed hosts, who together managed almost $5 \%$ of all active entire-home listings, were asked about the motivation to convert their properties into STRs and/or to invest in real estate. Additionally, 5 interviews were conducted with tenants displaced from their homes and 10 interviews with real estate agents, representatives of the organisation of property owners (Hellenic Property Federation) and of the National Association for the Protection of Tenants, lawyers involved in evictions, and with the deputy mayor for tourism of the municipality of Thessaloniki, in order to gain a deeper understanding of the effects of STRs on housing in the city.

\section{Airbnb hosts and professionalisation of STRs}

According to data from AirDNA, 3185 listings received at least one reservation in the municipality of Thessaloniki in the year between August 2018 and July 2019, and are therefore counted as "active listings" in this paper. The bulk of all active listings are entire homes $(90 \%)$. Private rooms make up $9.5 \%$ of active listings, whilst the number of shared rooms is insignificant, amounting to $0.5 \%$. This very high percentage of entire units is a first indicator of the commercial use of STRs, marking a significant difference to other cities where entire homes don't exceed two thirds of all listings - for example, the share of entire home listings is 51\% in New York (Wachsmuth and Weisler, 2018) and 57\% in Barcelona (Arias-Sans and Quaglieri-Dominguez, 2016). The majority of Airbnb listings is found in the city centre of Thessaloniki as is demonstrated in Figure 1, while only minor hotspots exist across the waterfront towards the south-east, confirming 
findings elsewhere on the high concentration of listings in city centres and areas with tourist attractions and tourism infrastructure (Arias-Sans and Quaglieri-Dominguez, 2016; Gutierrez et al., 2017).

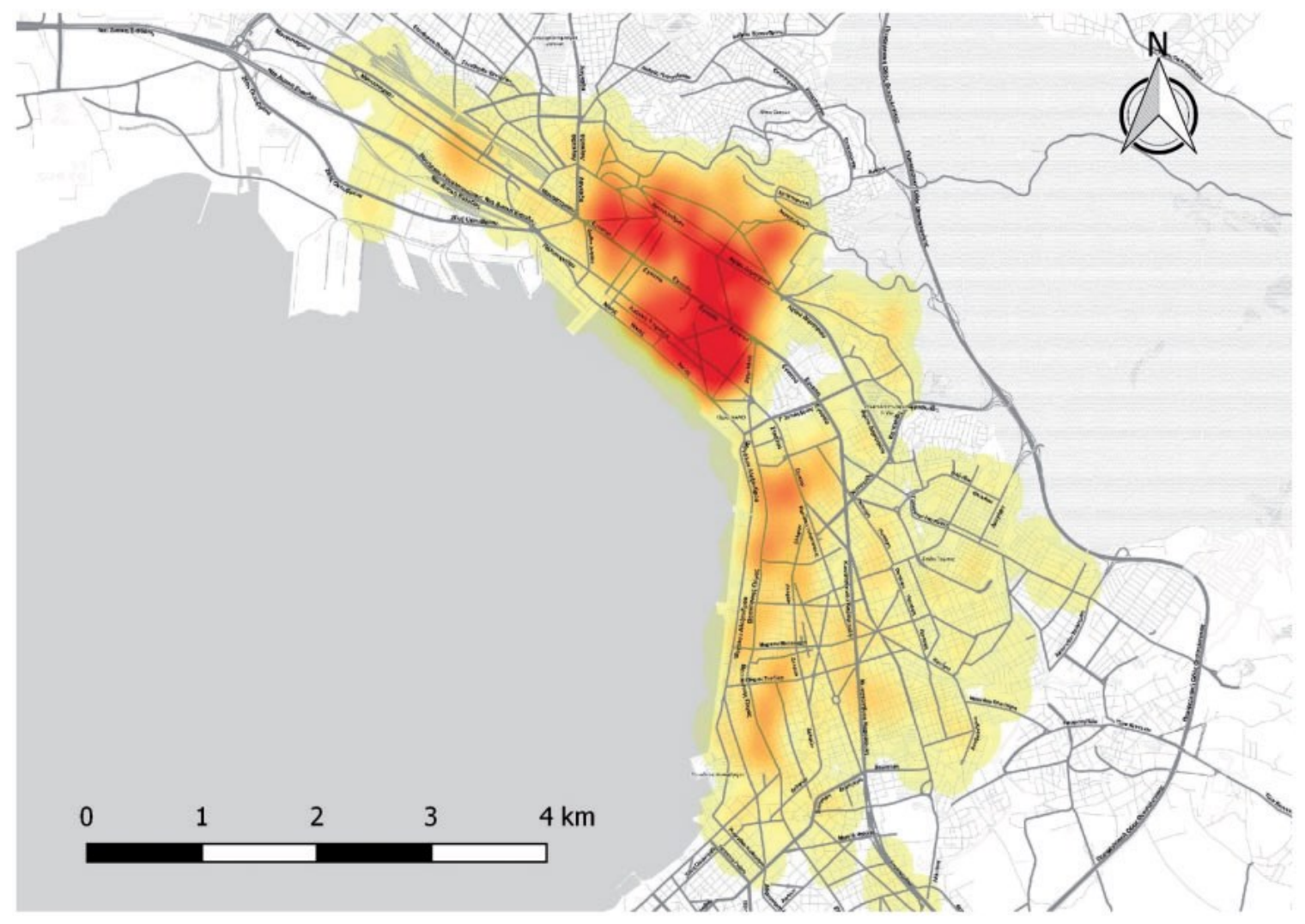

Figure 1. Density map of Airbnb listings in the municipality of Thessaloniki (August 2018 to July 2019)

The total annual host revenue from Airbnb between August 2018 and July 2019 amounted to $€ 12.2$ million (Figure 2); a $43 \%$ increase compared to the previous year. The average monthly revenue for active Airbnb listings was €660 in July 2019, which significantly exceeds the average monthly revenue from long-term rentals, according to real estate agents that I interviewed, as there are no official statistics about average rents. This promise of increased rental incomes given the general decrease in residential rental 
prices during the Greek crisis (Maloutas, 2014; Sapounakis and Katapidi, 2017), made the prospect of conversion to STRs extremely lucrative for homeowners. But, conversion to STRs has been part of different strategies by different types of hosts and is both found as an activity that provides a supplemental income and as a speculative activity by individuals, businesses and investors. The qualitative interviews that I conducted with Airbnb hosts allowed me to identify three different categories of suppliers. Residents sharing their homes or rooms is a first category. Private and shared rooms are, as already stated, of minor significance in Thessaloniki. But people sharing their home are also the exception, since the majority of entire-home hosts use additional properties and not their residence for STRs, as is evidenced in the interviews conducted. A second, more important, category of hosts includes individuals who did not invest in housing in recent years, but already owned second or multiple properties; local landlords who stopped renting to tenants in order to convert their properties to STRs, but also property owners whose flats were vacant. Wind et al. (2019) argue that in the Mediterranean countries second properties are predominantly vacant or used to house members of the extended family, and estimate that landlordism accounts for one third of all second property ownership in Greece. Given the social diffusion of property ownership, this category includes people from different backgrounds, and as a result people who are unemployed or in low paid employment, have been able to earn a considerable income by letting their second properties on Airbnb. Sofia ${ }^{4}$ who had been unemployed for two years and rents out one entire flat throughout the year argues:

There are months in which I make a thousand [euros], it's incredible. If I could do this systematically, I would be super happy financially. It is 
unbelievable, the solution that came from out of space. (...) That is a steady income I can rely on to cover expenses without worrying.

This category mainly comprises of single-listing hosts, who represent $81 \%$ (1565 hosts) of all active hosts with entire-home listings. As is argued by interviewees, a significant part of single-listing hosts already owned this property before the economic crisis. This is also true for a small share of hosts with more than one properties listed on Airbnb. While constituting 19\% (370) of active entire-home hosts, multiple-listing hosts provide $45.5 \%$ of the listings. But the larger part of multiple-listing hosts (and some single-listing hosts) are investors who purchased flats for STRs due to the decline in property prices in recent years. The third important category then, which gradually outstripped traditional landlords who became single-listing hosts, are individuals and companies investing in property for STRs due to the increased expected profitability. Such investments are strategic in the selection of locations and properties, using both buy-to-let and rent-to-rent strategies. This category includes landlords who started by renting out properties they already owned on Airbnb and decided to expand their operations. Yiannis, the co-founder of a company which now manages 10 full-time listings in Thessaloniki, which they rent from individual landlords and then sublet for STRs, recalls:

I started with one home, which I furnished and started letting on a shortterm basis. I did not have to buy the apartment as it was already family property. When I saw that the cost of furnishing and refurbishing had a return of investment in the same year, I realised that there is a niche in the 
housing market. So, because my best friends were unemployed at that time, we decided to start something more serious.

The existence of second/multiple properties here acts as a catalyst for further investments, providing the initial capital required for the purchase or rental of additional properties, and contributes to the concentration of property ownership among wealthier households (Ronald and Kadi, 2018). The declining residential property prices in Thessaloniki eased the acquisition of properties for STRs as an investment. Due to the collapse of bank lending during the Greek crisis, the majority of property transactions is made using equity according to real estate agents, and thus buyers hardly spend over $€ 100,000$ (exceptions include purchases of high-profile properties by international investors and the golden visa program). Similar to pioneer gentrifiers (Smith, 1996), middle-class individuals invest their personal savings and may use sweat equity in refurbishments in order to become Airbnb hosts. But local entrepreneurs including construction companies and real estate agents have also invested in housing, partially changing the focus of their operations, sensing the profit opportunities through STRs from devalorised properties due to tourist consumption demand. Giorgos, who became a professional in STRs in recent years by gradually buying apartments in the city centre, describes this process:

Real estate prices were falling in Thessaloniki, so with my cousin we talked about buying properties. We did a survey of the market, we saw a lot of houses, and I made my first move with a very small studio, as an 
experiment, which we renovated. After three months I made the next move, I bought a slightly larger studio flat, which we also refurbished. I quickly realized that there was this market, there was demand, and at that stage I had contact with a number of people interested in investing, and that way, while we did not have the financial ability to do other purchases ourselves, with these agreements, we bought more flats, which we operate as a team. We now have 7 properties in Thessaloniki, and this was done in 2 years only.

Real estate investments have been made by both national and international investors, but the influence of the latter has been relatively moderate so far. Property transactions have increased in recent years and according to real estate agents most buyers are local investors, followed by middle-class individuals from neighbouring countries, although there is evidence of bigger real estate transactions recently by investors purchasing whole buildings. The majority of landlords who use property management companies are also locals, who prefer the services provided by such intermediaries to managing the properties themselves, and people who have moved to other cities or abroad and therefore require a local agent. On the contrary, the impact of immigrant investor initiatives such as the golden visa program, which grants residence permits in Greece and freedom of movement in the Schengen zone to non-EU citizens who purchase properties of a value over $€ 250,000$, has been considerably low in Thessaloniki's housing market. Property purchased through this program is often converted to 
STRs (Montezuma and McGarrigle, 2019), but in the metropolitan area of Thessaloniki only 128 permits have been granted since the program started in 2013 (Ministry of Citizen Protection, 2019).

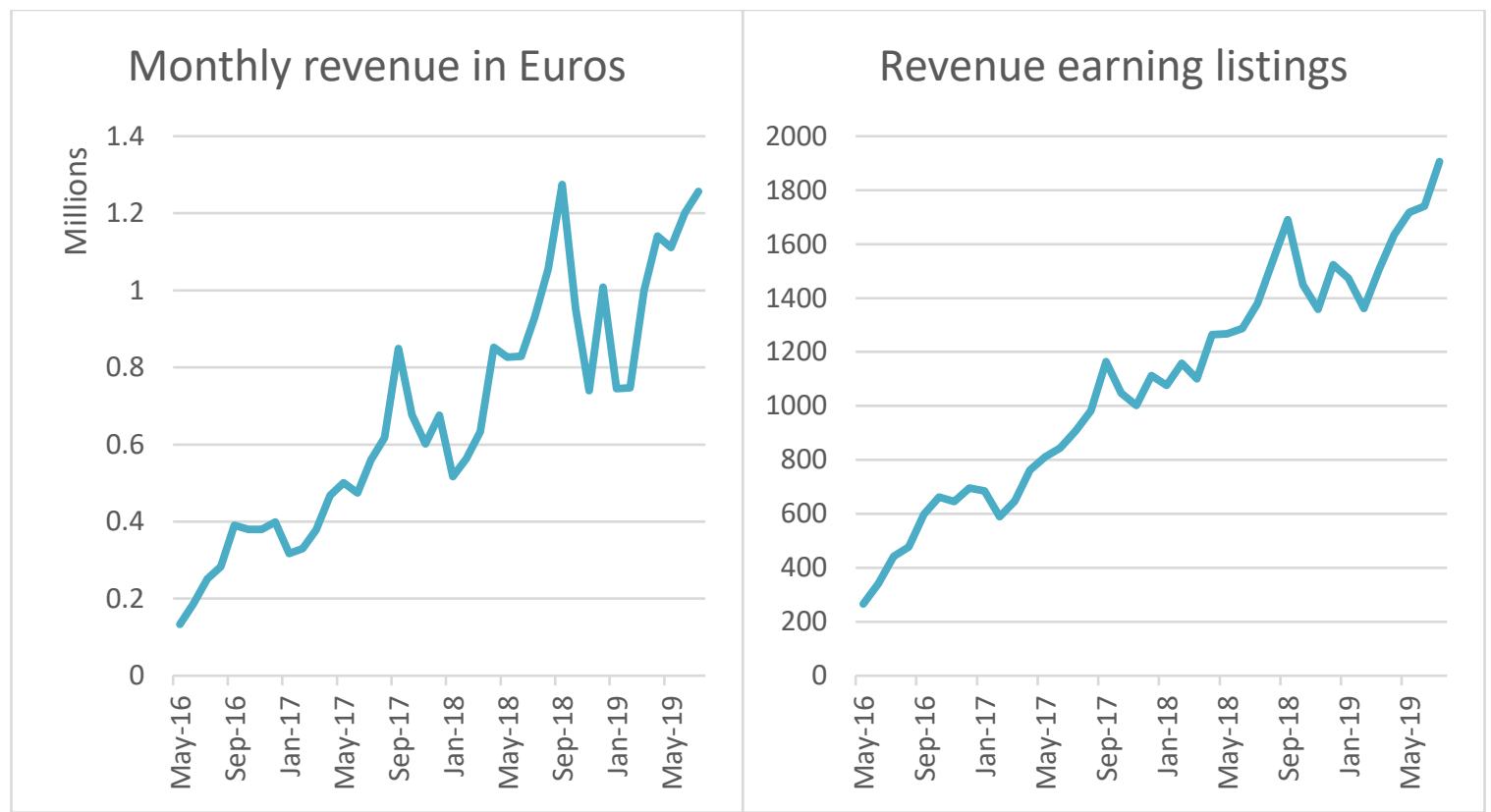

Figure 2. Total monthly Airbnb host revenue (left) and Revenue earning monthly Airbnb listings (right) in the municipality of Thessaloniki (May 2016 - July 2019)

While the number of Airbnb listings increases continuously, growth slowed down during the last year (Figure 2) and average monthly revenues and daily rates have started to decline. These developments have created the perception among hosts that the STR market has been saturated. Without necessarily having access to detailed information regarding the growth of STRs, hosts argue that prices and revenues have dropped given increased competition by different types of hosts. The expansion of the operation of 
professional hosts is seen as major problem, as these have capital available to invest in refurbishments and are able to provide services that are comparable to the formal hospitality sector. From the perspective of an individual host with one entire-home listing, Sofia argues:

For the first two, maybe three years, the number of guests was great. Then it began to decrease. I saw that countless listings were added to the site, that there was now tremendous competition, that is, people entered the market who did it professionally, who had 3-4 properties, that were professionally renovated and that in the photographs looked like a hotel built for this cause; they no longer were normal houses that were rented, and for me this was the biggest competition.

On the contrary, professional hosts are mainly concerned with the addition of numerous listings by amateur and single-listing hosts to the platform, which are increasing supply and driving down monthly revenues. In the words of Yiannis:

For us as a company, the disaster began from the moment that Airbnb became so widely known in Greece. So everyone lists their house, they tell their children to manage it [on the online platform] and they think it'll work that way. Okay, gradually we will see who the professional is and who has a vision. (...) I think that we have reached the point of satiety. Not that no more new listings will be added, but for our listings, we cannot charge the daily prices that we did a few years ago. 


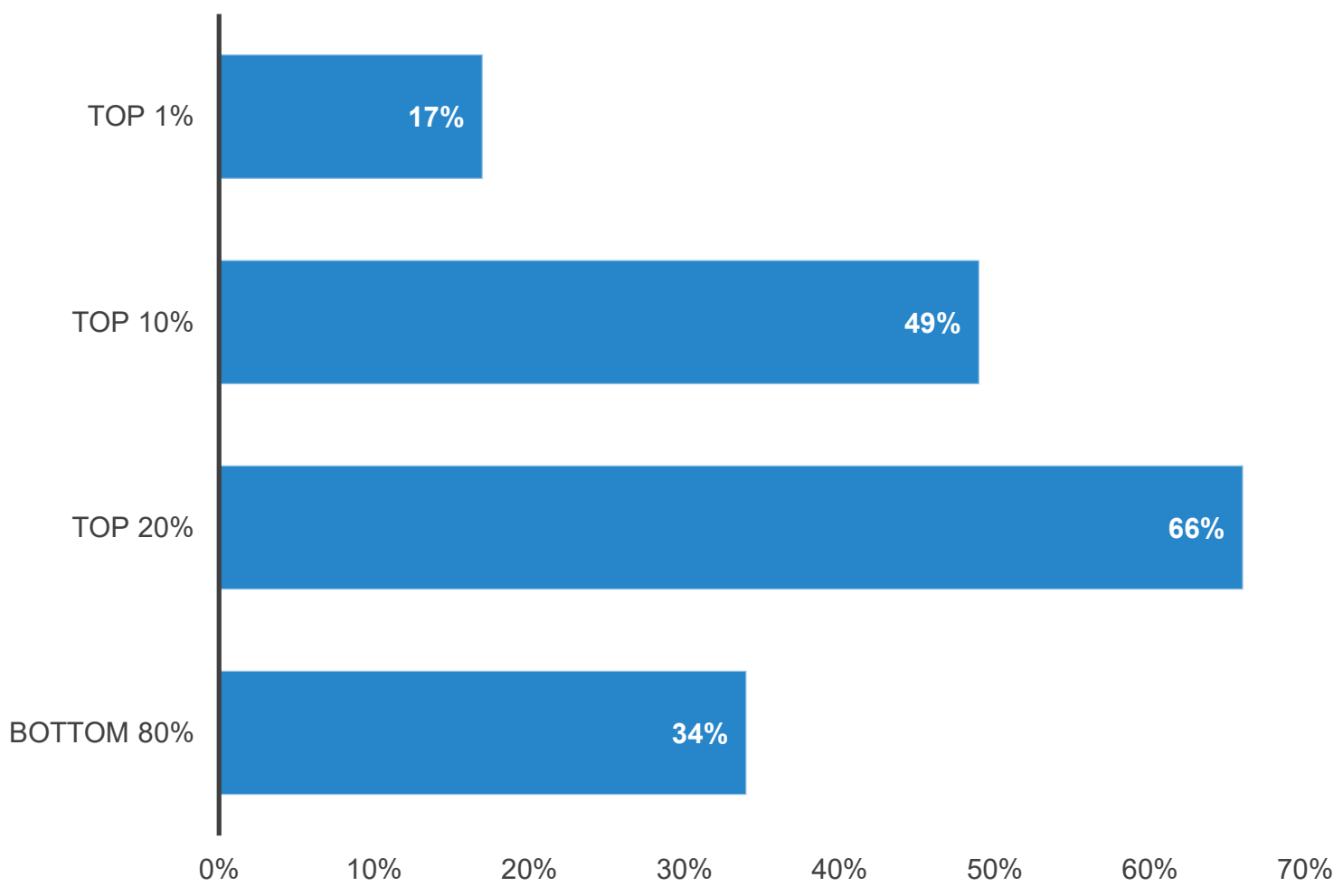

Figure 3. Concentration of annual host revenue in the municipality of Thessaloniki (August 2018 - July 2019) Source: Author's elaboration of AirDNA data

In addition to the large number of listings added to the platform, profitability has also been squeezed by the implementation of measures for the taxation of STRs. While hosts were previously able to evade taxation by not declaring their income, the creation of a registry of listings to enforce legislation in late 2018 and the threat of fines for noncompliance have led to the reduction in net incomes. As a result of these developments, some landlords are re-converting their homes to long-term rentals given increased demand and prices for these and their inability to compete with established professional 
hosts. The dominance of professional hosts in the STR market in Thessaloniki also becomes evident by the extreme concentration of revenues. 21 hosts, accounting for $1 \%$ of all active hosts (2098 hosts) earned 17\% of the annual revenue (Figure 3). These hosts are managing from 3 to 36 listings ( 215 in total) and include at least 7 property management companies, while there is no evidence that any of these hosts are international investors. Almost half of all revenue (49\%) is made by $10 \%$ of the hosts, further indicating the extreme concentration of profits at the top. But this opportunity to profit from rents through the conversion to STRs and the expansion of the influence of professional hosts may have adverse consequences for the right of tenants to stay put in the city.

\section{Towards the STR induced displacement of tenants}

The increase in the number of STRs does not necessarily result in the reduction of housing available for long-term rental (Wachsmuth and Weisler, 2018). Homes or rooms listed on Airbnb may for example be rented out by hosts while they are on holiday or hosts might only rent a spare room - in other words still use the home as their primary residence - and thus will not contribute to the loss of housing for long-term rental. On the contrary, if an entire-home listing is rented and/or available on Airbnb throughout the year, it probably does not simultaneously house long-term occupants. If properties are utilised permanently for STRs, the housing options for (potential) long-term residents are reduced (Cocola-Gant, 2016). This reduction may occur through direct displacement, the eviction of households for the conversion of properties to STRs, or exclusionary 
displacement, as the reduction of the available housing stock makes it extremely difficult for households to find (previously) affordable properties in that area (Marcuse, 1985).

The definition of STR full-time occupancy for calculating the number of listings that have been permanently removed from the long-term rental market has been subject of debates, even involving representatives of Airbnb. Insideairbnb (2020) uses a threshold of 60 days booked per year for what it calls "frequently booked" listings, which are defined as "entire homes or apartments highly available and rented frequently yearround to tourists". Wachsmuth and Weisler (2018) use a more conservative estimate of 60 days or more booked and additionally at least 120 days available for booking, in order to exclude occasional, but highly successful rentals. Both indicators have limitations; the first one, for instance, does not account for full-time hosts who are unable to achieve an occupancy of 60 days per year. The latter indicator on the other hand is unable to account for highly successful listings which have been recently added to Airbnb; in the case of Thessaloniki there are 800 new listings in $2019,25 \%$ of which have been booked for at least 60 days, but none has reached the 120 days availability threshold. An additional constraint to calculating full-time STR use is the number of blocked days (days on which the property was not booked or available on Airbnb), which can be interpreted either as days on which the listing is used by the host for housing or days on which it is booked on another platform. Interviews with hosts revealed that almost all of them simultaneously advertise their listings on several channels to maximise bookings. Due to these limitations in calculating listings permanently removed from the housing market satisfactorily, I decided to use the simple 60 days or more booked per year threshold, 
which might potentially result in understating the actual impact of STRs on the housing market.
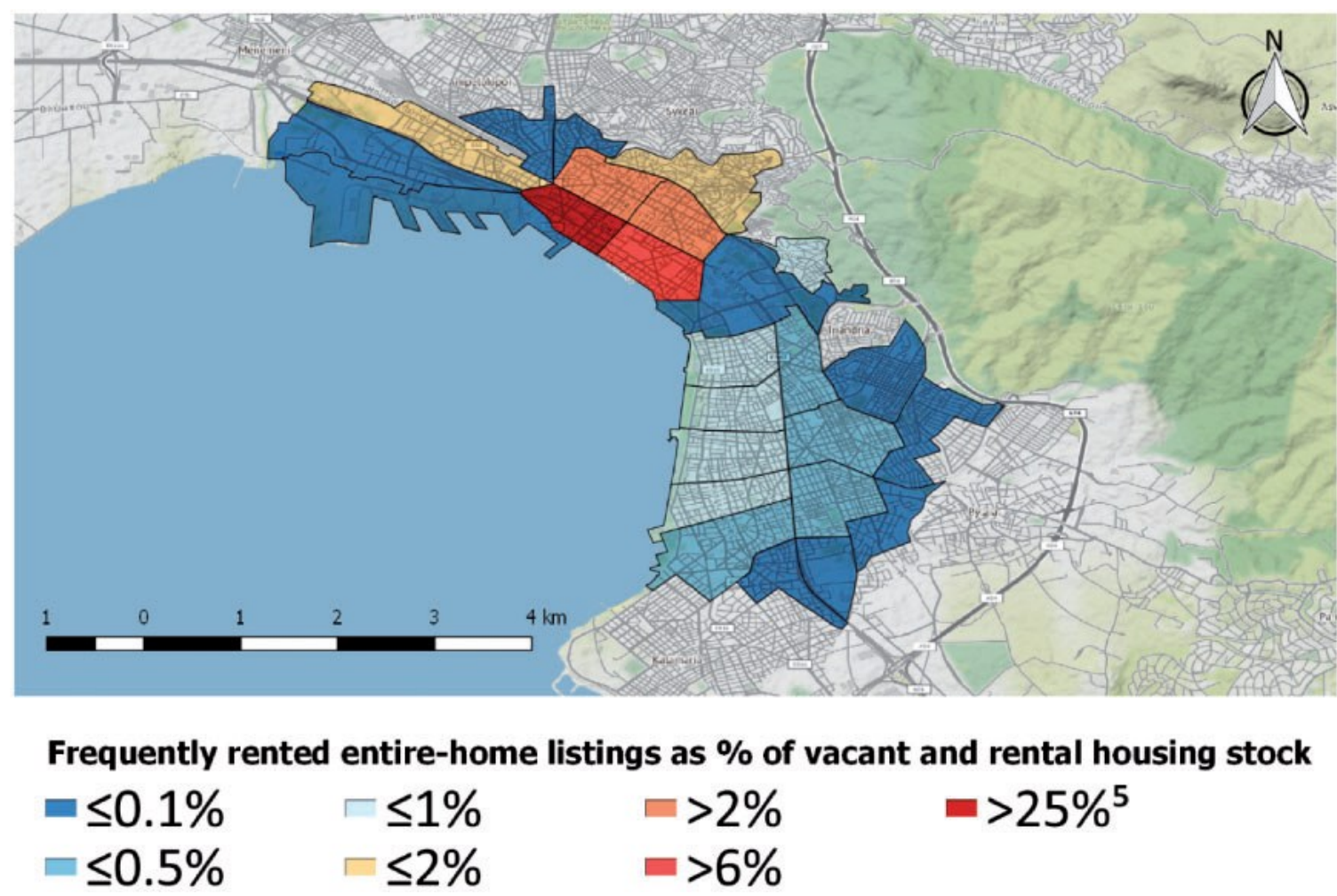

Figure 4. Frequently rented entire-home Airbnb listings as \% of vacant and rental housing in the municipality of Thessaloniki (August 2018 to July 2019)

In the period between August 2018 and July 2019, 1531 entire-home listings (53\% of active entire-home listings) were rented 60 days or more in the municipality of Thessaloniki. I compared the number of frequently-rented entire-home listings to the amount of empty and rental housing in each neighbourhood of the municipality using the 2011 census data on housing tenure and vacancy at building block level (ELSTAT, 2011), in order to estimate the percentage of housing converted into full-time STRs and thus permanently removed from the long-term rental market. As Figure 4 demonstrates, 
significant losses to Airbnb of more than $25 \%{ }^{5}$ and $6 \%$ respectively of the empty and rental housing stock are found in the two neighbourhoods which constitute the city centre of Thessaloniki, where there is also a high concentration of hotels. In these neighbourhoods, the number of homes removed from the long-term housing market is a considerable percentage of the housing stock that would be available to households for rent, while in other parts of the municipality the impact of STRs is substantially lower. Whether the properties that have been turned into full-time STRs were homes from which tenants had to be evicted (direct displacement), were converted after they became empty when tenants left voluntarily or stood empty for years (both contributing to exclusionary displacement), is difficult to ascertain.

Regarding those displaced, in addition to the difficulties in identifying direct displacement (Newman and Wyly, 2006), there are no data accessible on housing evictions in Greece at city level (Sapounakis and Katapidi, 2017). However, I conducted 5 interviews with tenants evicted for the conversion of homes to STRs, who were identified with the help of gatekeepers, and additional interviews with lawyers specialising in evictions, which substantiated that direct displacement is taking place in Thessaloniki by landlords converting their properties to STRs. The majority of evictions occur after the end of rental contracts, which legally run for a minimum of three years, when landlords can increase the rents freely and vacate the property without a legal procedure. Maria, a public employee, argued:

The landlord asked for an increase of $€ 100$ per month for the renewal of the contract, saying that he could make more money through Airbnb. We could not 
afford to stay and found a flat in the western part of the municipality with about the same rent.

Similarly, Nikos, a lawyer who was displaced from the flat that he rented, located on the city's main square, Aristotle Square, explained:

I had to leave my home as the owner did not want to renew the contract after the three years. She preferred to turn it into an Airbnb. This probably didn't go well, as I've heard that she's now trying to rent the flat for €650-700. I was paying $€ 400$; that's a huge increase.

This quote also points to the difficulty that amateur hosts face in converting their properties to STRs, given increased competition by more professional hosts.

Concurrently, it demonstrates how exclusionary displacement has been encouraged by the reduction of housing available for long-term rent in the city centre and the increase in rents. Data by the real estate company REMAX show an average increase in rental prices in the city centre of Thessaloniki by 16\% between 2015 and 2018 (REMAX, 2016, 2017, 2018), which is confirmed by real estate agents that I interviewed, with smaller increases in rents in the rest of the municipality. Tenants displaced from (but also those willing to move to) the city centre face increasing difficulty in finding affordable housing and are forced to move to adjacent neighbourhoods.

Due to widespread small-scale property ownership, low residential mobility, and the low degree of ethnic and social segregation (Kafkalas et al., 2008; Leontidou, 1990), displacement was limited in the past and Thessaloniki, as Greek cities generally, had been considered ungentrifiable (Maloutas et al., 2012). Gentrification had also been 
impeded by the impaired supply of adequate properties, as the type, quality, and aesthetics of the available housing stock are not desirable or advantageous to residential gentrification (Maloutas and Karadimitriou, 2001), with the exception of the preserved neighbourhood of the Upper Town, which underwent a process of micro-gentrification in the 1990s and early 2000s (Hastaoglou, 2011; Kafkoula, 2004). Low local demand for rental housing and relatively low rental prices did not foster investment in housing and/or in refurbishments in the previous decade, while the economic crisis contributed to the devalorisation of housing. But tourism growth in recent years, the higher consumption power of tourists compared to the local middle-class, and the resulting expectation of increased capital accumulation initiated a process of conversion of housing to STRs and of buy-to-let investment. While apartment buildings and especially lower floor apartments were unattractive to potential residential gentrifiers, refurbishment made them attractive to short-term visitors who do not necessarily desire the standards associated with longer-term living, such as views or apartment size, but primarily seek central locations and/or proximity to tourist attractions (Balampanidis et al., 2019).

As a result, tourism gentrification has been fueled with the revalorisation of the built environment, the displacement of tenants for conversion of housing to STRs, and the increase in rents and decrease in the options for long-term rental. In the two neighbourhoods of Thessaloniki's city centre there has been a cumulative reduction of at least $7 \%$ of rental and vacant housing, posing an important threat to housing availability and affordability. But the overall effects of the permanent removal of homes from the rental sector are (still) partially tempered by the availability of housing in other 
neighbourhoods in close proximity and by the lack of sufficient tourism demand compared to other cities in Southern Europe.

\section{Conclusion}

This paper argues that in secondary cities where gentrification had been limited, the extraction of higher rents through STRs leads to (micro-)entrepreneurialism and reinvestment in real estate by different types of hosts and fuels gentrification. Extra-local demand results in the displacement of tenants, the reduction of housing options and the increase in rents in STR hotspots. The analysis adds to research on the suppliers of STRs (Cocola-Gant and Gago, 2019; Semi and Tonetta, 2020), showing the role of local homeowners and investors in the development of this housing market segment. In the context of austerity and increased property taxation in Thessaloniki, the conversion of second properties to STRs provided an important source of income to homeowners in the city centre. But given the renewed importance of rent as a form of accumulation smallscale investors and property management companies outcompeted amateur hosts due to their housing wealth and the capital they can invest in buy-to-let or rent-to-rent housing and refurbishments. The competition between hosts led to the professionalisation of STRs, to the concentration of revenues, and to the reconversion of some housing to longterm rentals, albeit for higher rents.

To an extent, the growth and effects of STRs in Thessaloniki resemble the experience of other places. However, the type and scale of investors involved, and the impact of gentrification reflect social, cultural, political and institutional dynamics 
(Bernt, 2016), the intensity of tourism and lifestyle migration, and the attractiveness of real estate markets to global investment (Rogers and Koh, 2017). Unlike cities with larger housing market investment opportunities (Cocola-Gant and Gago, 2019), transnational individual and corporate investors have not become important actors in STRs, nor have STRs contributed to the post-crisis financialisation of housing. Neither has transnational gentrification gained ground, as it has in other secondary cities in Southern Europe in combination with STRs (Carvalho et al., 2019; Jover and Diaz-Parra, 2019), making gentrification more pronounced than in Thessaloniki.

But state government policies to attract global real estate investment in Greece, may shift this dynamic and contribute to upscaling the process to fifth-wave gentrification (Aalbers, 2019). So far, institutional investors, including real estate investment trusts and private equity, which have been major actors in the financialisation of rental housing (Janoschka et al. 2019; Wijburg et al., 2018), have exclusively invested in commercial properties in Greece. Nevertheless, the levels of mortgage arrears remain high and the legal protection of primary residences from foreclosure has largely been overturned, creating the condition for the dispossession of homeowners. Property foreclosures have sped up since the introduction of online auctions in 2018, with the majority of properties being bought by the lenders/banks themselves, making the acquisition of significant volumes of residential real estate by investors possible. It would thus be important to explore how investment in STRs is connected to other investment strategies in rental housing, as long-term rents and property values have started to increase, and whether Airbnb-led investment would attract further competition from institutional investors. The impact of countertendencies would also need to be explored, 
especially in the context of the COVID-19 pandemic, which, at least in the short run, has put a halt to the visitor-based extraction of rents, potentially increasing the supply of properties in the rental market.

\section{Notes}

1 Thessaloniki does not have an urban government structure, but is divided into seven self-governing municipalities. In this paper, I focus on the municipality of Thessaloniki, where Airbnb activity is concentrated, as the share of STRs is insignificant in the six other municipalities of the urban area of Thessaloniki. In none of these does the percentage of STRs exceed $0.1 \%$ of the vacant and rental housing stock.

2 In the other municipalities of the city owner-occupation is significantly higher (minimum 71.5\%), while the vacancy rate does not exceed $22 \%$.

3 One neighbourhood of the municipality, Triandria, was not included in the analysis as it was not part of the AirDNA dataset.

4 The names of interviewees have been changed to protect their anonymity.

5 This number is a significant overestimate, as a large share of STRs in this neighbourhood are located in former light-industrial buildings which have been converted to housing units during the last years. 


\section{References}

Aalbers M (2019) Revisiting 'The changing state of gentrification' - Introduction to the Forum: From third to fifth-wave gentrification. Tijdschrift voor Economische en Sociale Geografie 110(1): 1-11.

Alexandri G and Janoschka M (2018) Who loses and who wins in a housing crisis? Lessons from Spain and Greece for a nuanced understanding of dispossession. Housing Policy Debate 28(1): 117-134.

Allen J, Barlow J, Leal J, Maloutas T and Padovani L (2008) Housing and welfare in Southern Europe. John Wiley \& Sons.

Arias-Sans A and Quaglieri-Dominguez A (2016) Unravelling airbnb: Urban perspectives from Barcelona. In: Russo AP and Richards G (eds) Reinventing the local in tourism: Producing, consuming and negotiating place. Channel View Publications, pp. 209-228.

Arbaci S (2019) Paradoxes of segregation: Housing systems, welfare regimes and ethnic residential change in Southern European cities. John Wiley \& Sons.

Balampanidis D, Maloutas T, Papatzani E and Pettas D (2019) Informal urban regeneration as a way out of the crisis? Airbnb in Athens and its effects on space and society. Urban Research \& Practice.

https://doi.org/10.1080/17535069.2019.1600009 
Bank of Greece (2020) New Index of apartment prices by geographical area. Available at: https://www.bankofgreece.gr/BogDocumentEn/NEW_INDEX_OF_APARTMENT_ PRICES_BY_GEOGRAPHICAL_AREA.PDF (accessed 31 July 2020)

Bernt M (2016) Very particular, or rather universal? Gentrification through the lenses of Ghertner and López-Morales. City 20(4): 637-644.

Beswick J, Alexandri G, Byrne M, Vives-Miró S, Fields D, Hodkinson S, and Janoschka M (2016) Speculating on London's housing future: The rise of global corporate landlords in 'post-crisis' urban landscapes. City 20(2): 321-341.

Betancur J J (2014) Gentrification in Latin America: Overview and critical analysis. Urban Studies Research http://dx.doi.org/10.1155/2014/986961

Botsman R and Rogers R (2011) What's mine is yours: how collaborative consumption is changing the way we live. London: HarperCollins Business.

Carvalho L, Chamusca P, Fernandes J and Pinto J (2019) Gentrification in Porto: floating city users and internationally-driven urban change. Urban Geography 40(4): 565572

Cocola Gant A (2016) Holiday rentals: The new gentrification battlefront. Sociological Research Online, 21(3): 10.

Cocola-Gant A (2018) Tourism gentrification. In: Lees L and Phillips M (eds) Handbook of gentrification studies. Edward Elgar Publishing, pp. 281-293. 
Cocola-Gant, A. and Gago, A., 2019. Airbnb, buy-to-let investment and tourism-driven displacement: A case study in Lisbon. Environment and Planning A https://doi.org/10.1177/0308518X19869012

Colomb C and Novy J (eds) (2017) Protest and resistance in the tourist city. Routledge.

ELSTAT (2011): General censuses of buildings and population-housing.

ELSTAT (2019) Building activity in 2019 by municipality. Available at: https://www.statistics.gr/en/statistics/-/publication/SOP03/2019-M12 (accessed 30 November 2020).

ELSTAT (2020) Hellenic Statistical Authority press release: activities of notaries 2019. Available at: https://www.statistics.gr/en/statistics/-/publication/SJU24/2019 (accessed 30 November 2020).

Emmanuel D (2004) Socio-economic Inequalities and Housing in Athens: Impacts of the Monetary Revolution of the 1990s. The Greek Review of Social Research 113: 121143.

Emmanuel D (2014) The Greek System of Home Ownership and the Post-2008 Crisis in Athens. Region et Developpement 39: 167-182.

Fields D (2019) Automated landlord: Digital technologies and post-crisis financial accumulation. Environment and Planning A. https://doi.org/10.1177/0308518X19846514

Geerts W (2018) Top 100 City Destinations 2018. Euromonitor International 
Gotham KF (2005) Tourism gentrification: The case of New Orleans' Vieux Carre (French Quarter). Urban studies 42(7): 1099-1121.

Gurran N and Phibbs P (2017) When tourists move in: How should urban planners respond to Airbnb? Journal of the American Planning Association 83(1): 80-92.

Gutiérrez J, García-Palomares JC, Romanillos G, and Salas-Olmedo MH (2017) The eruption of Airbnb in tourist cities: Comparing spatial patterns of hotels and peer-topeer accommodation in Barcelona. Tourism Management 62: 278-291.

Hadjimichalis C (2018) Crisis Spaces: Structures, Struggles and Solidarity in Southern Europe. Routledge.

Hastaoglou-Martinidis V (2011) Rehabilitation of Historic Sites in Thessaloniki: Protection, New Building and Re-Use. In: Chronocity. Sensitive Interventions in Historic Environment, Florence: Alinea editrice 15-17.

InsideAirbnb (2020) Inside Airbnb: Athens. Adding data to the debate. Available at: http://insideairbnb.com/athens/ (accessed 31 July 2020).

Ioannides D, Röslmaier M, and van der Zee E (2018) Airbnb as an instigator of 'tourism bubble'expansion in Utrecht's Lombok neighbourhood. Tourism Geographies. https://doi.org/10.1080/14616688.2018.1454505

Janoschka M, Alexandri G, Ramos H O and Vives-Miró S (2019) Tracing the sociospatial logics of transnational landlords' real estate investment: Blackstone in 
Madrid. European Urban and Regional Studies.

https://doi.org/10.1177/0969776418822061

Jover J and Díaz-Parra I (2019) Gentrification, transnational gentrification and touristification in Seville, Spain. Urban Studies https://doi.org/10.1177/0042098019857585

Judd DR and Fainstein SS (eds) (1999) The tourist city. Yale University Press.

Kadi J, Plank L, and Seidl (2019) Airbnb as a tool for inclusive tourism? Tourism Geographies https://doi.org/10.1080/14616688.2019.1654541

Kafkalas G, Labrianidis L and Papamichos N (eds) (2008) Thessaloniki on the Verge: The city as a process of change. Athens: Kritiki.

Kafkoula K (2004) Imiter le patrimoine: le développement régulé du quartier historique d'Ano Polis à Thessalonique. In: Gravari-Barbas M (ed) Habiter le patrimoine. Presses universitaires de Rennes, pp. 171-186.

Kallis G (2017) In Defense of Degrowth: Opinions and Minifestos. Uneven Earth Press.

Karaliotas L (2017) Performing neoliberalization through urban infrastructure: Twenty years of privatization policies around Thessaloniki's port. Environment and Planning A 49(7): 1556-1574. 
Katsinas P (2019) The international face of Thessaloniki: The "Greek crisis," the entrepreneurial mayor, and mainstream media discourses. Area 51(4): 788-796.

Labrianidis L (2011) Thessaloniki's arrested development: Missed opportunities. Antipode 43(5): 1801-1827.

Lee D (2016) How Airbnb short-term rentals exacerbate Los Angeles's affordable housing crisis: Analysis and policy recommendations. Harvard Law \& Policy Review 10: 229-253.

Lees L, Shin H B and López-Morales E (2016) Planetary gentrification. John Wiley \& Sons.

Leontidou L (1990) The Mediterranean city in transition: Social change and urban development. Cambridge University Press.

Ley D and Dobson C (2008) Are there limits to gentrification? The contexts of impeded gentrification in Vancouver. Urban Studies 45(12): 2471-2498.

Maitland R (2010) Everyday life as a creative experience in cities. International Journal of Culture, Tourism and Hospitality Research 4(3): 176-185.

Maloutas T (2003) The self-promoted housing solutions in post-war Athens. EKKE Discussion Paper Series 9

Maloutas T (2014) Social and spatial impact of the crisis in Athens: from clientelist regulation to sovereign debt crisis. Région et Développement 39: 149-166. 
Maloutas T (2018) Travelling concepts and universal particularisms: A reappraisal of gentrification's global reach. European Urban and Regional Studies 25(3): 250-265.

Maloutas T, Arapoglou V, Kandylis G and Sayas J (2012) Social polarization and desegregation in Athens. In: Maloutas T and Fujita K (eds) Residential Segregation in Comparative Perspective. Making Sense of Contextual Diversity. Routledge, pp. 257-285.

Maloutas T and Karadimitriou N (2001) Vertical social differentiation in Athens: alternative or complement to community segregation? International Journal of Urban and Regional Research 25(4): 699-716.

Mantouvalou M, Mavridou M and Vaiou D (1995) Processes of social integration and urban development in Greece: southern challenges to European unification. European Planning Studies 3(2): 189-204.

Marcuse P (1985) Gentrification, abandonment, and displacement: Connections, causes, and policy responses in New York City. Washington University Journal of Urban and Contemporary Law 28: 195-239.

Mermet AC (2017) Airbnb and tourism gentrification: critical insights from the exploratory analysis of the 'Airbnb syndrome' in Reykjavik. In: Gravari-Barbas M and Guinard S (eds) Tourism and Gentrification in Contemporary Metropolises. Routledge, pp. 52-74. 
Ministry of Citizen Protection (2019) Residence permits to investors. Available at: https://web.archive.org/web/20190708183838/https://www.enterprisegreece.gov.gr/e n/greece-today/living-in-greece/residence-permits (accessed 31 July 2020).

Montezuma J and McGarrigle J (2019) What motivates international homebuyers? Investor to lifestyle 'migrants' in a tourist city. Tourism Geographies 21(2): 214234.

Newman K and Wyly E (2006) The right to stay put, revisited: Gentrification and resistance to displacement in New York City. Urban studies 43(1): 23-57.

Paccoud A (2017) Buy-to-let gentrification: Extending social change through tenure shifts. Environment and Planning A 49(4): 839-856.

Remax (2016) Nationwide survey of RE/MAX Greece about trends of renting for 2016. Available at: https://www.remax.gr/news/382 (accessed 31 July 2020).

Remax (2017) Nationwide survey of RE/MAX Greece about trends of renting for 2017. Available at: https://www.remax.gr/news/439 (accessed 31 July 2020).

Remax (2018) Nationwide survey of RE/MAX Greece about trends of renting for 2018. Available at: https://www.remax.gr/news/485 (accessed 31 July 2020).

Rogers D and Koh SY (2017) The globalisation of real estate: the politics and practice of foreign real estate investment. International Journal of Housing Policy 17(1): 114. 
Ronald R and Kadi J (2018) The revival of private landlords in Britain's posthomeownership society. New Political Economy 23(6): 786-803.

Sapounakis A and Katapidi I (2017) Evictions from Primary Residences in Greece: Methodological Concerns Regarding the Collection of Data from Civil Courts' Records for Tenancies. European Journal of Homelessness 11(2): 149-162.

Schäfer P and Braun N (2016) Misuse through short-term rentals on the Berlin housing market. International Journal of Housing Markets and Analysis 9(2): 287-311.

Semi G and Tonetta M (2020) Marginal hosts: Short-term rental suppliers in Turin, Italy. Environment and Planning A: Economy and Space https://doi.org/10.1177/0308518X20912435

Siatitsa D (2016) Changes in housing and property under the austerity regime in Greece. Challenges for movements and the left. Schönig B and Schipper S (eds) Urban Austerity: Impacts of the Global Financial Crisis on Cities in Europe. Berlin, Theater der Zeit, pp.145-160.

Shaw K (2004) Local limits to gentrification. In: Atkinson R and Bridge G (eds.) Gentrification in a global context. Routledge. pp. 172-188

Slater T (2017) Planetary rent gaps. Antipode 49: 114-137.

Slee T (2017) What's yours is mine: Against the Sharing Economy. Or Books.

Smith N (1996) The new urban frontier: Gentrification and the revanchist city. Routledge. 
Sperling G (2015) How Airbnb Combats Middle Class Income Stagnation. Available at https://www.cedarcityutah.com/wp-content/uploads/2015/07/MiddleClassReportMT-061915_r1.pdf

Sundararajan A (2016) The sharing economy: The end of employment and the rise of crowd-based capitalism. MIT Press.

Thessaloniki Hotel Association (2020) Press release. Nationalities 2019. Available at: http://www.tha.gr/default.aspx?lang=el-GR\&page=52\&newsid=469 (accessed 31 July 2020).

Wachsmuth D and Weisler A (2018) Airbnb and the rent gap: Gentrification through the sharing economy. Environment and Planning A: Economy and Space 50(6): 11471170.

Wijburg G, Aalbers M B and Heeg S (2018) The financialisation of rental housing 2.0: Releasing housing into the privatised mainstream of capital accumulation. Antipode 50(4): 1098-1119.

Wind B, Dewilde C and Doling J (2020) Secondary property ownership in Europe: Contributing to asset-based welfare strategies and the 'really big trade-off'. International Journal of Housing Policy 20(1): 25-52.

World Bank (2020) International tourism, number of arrivals to Greece. World Tourism Organization, Yearbook of Tourism Statistics, Compendium of Tourism Statistics. 
Available at: https://data.worldbank.org/indicator/ST.INT.ARVL?locations=GR (accessed 31 July 2020).

Wyly E (2015) Gentrification on the planetary urban frontier: The evolution of Turner's noösphere. Urban Studies 52(14): 2515-2550.

Yrigoy I (2019) Rent gap reloaded: Airbnb and the shift from residential to touristic rental housing in the Palma Old Quarter in Mallorca, Spain. Urban Studies 56(13): $2709-2726$. 